\title{
العملية التخطيطية للمدن الصغيرة في العراق
}

\author{
الدكتور نجيل كمال عبد الرزاق \\ قسم الهندسة المعمارية \\ الجامعة التكنولوجية
}

الخلاصة

ان التخطيط للمدن الصغيرة في العراق في غاياته وأسسه بعتمد النظرة المستقبلية للنوض بها وتغيير طابعـــها

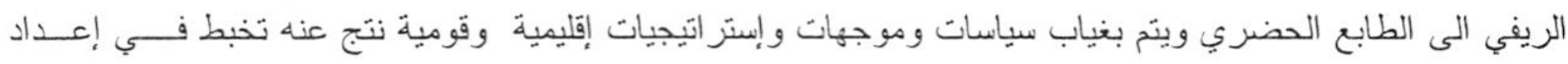

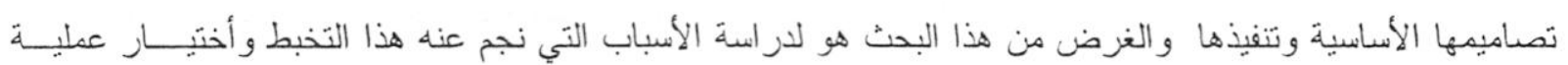

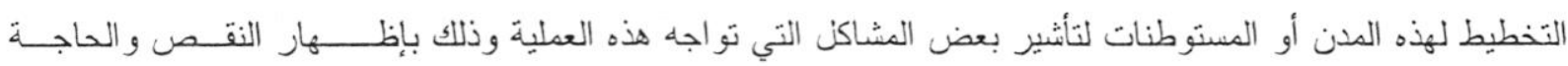

بالإضافة الى الضعف في حلقاتها المختلفة.

\begin{abstract}
$\underline{\text { Abstract }}$
The planning for small towns in Iraq in it's objectives and principles, based on future development of these towns to change its ruler character urban feature, is carried out in absence of national and regional policies, directives and strategies, this led to ambiguous Master-plans preparation and implementation. The purpose of this paper is to study the reasons of this ambiguity and examine the planning process of these towns or settlements to indicate some of the problems which are likely has impeded this process to draw attention to the shortages and demand as well as to some of weakness in its different chains.
\end{abstract}


الأول قامت به شركات اجنبية لمصلحة المديريسة

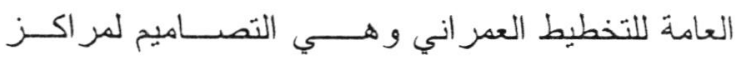

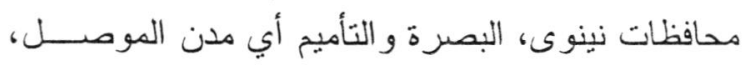
البصرة وكركوك (0) حالها حال مدينة بغداد (1) و الثناني

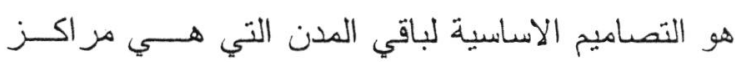

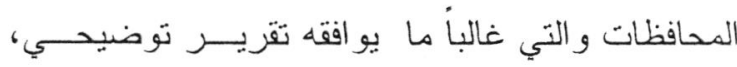
و الثالث المدن التي هي مر اكز الاقضية و التي يو افـــق بعضها فقط نقرير موجز ، اما الر ابع فهو لمدن مر اكـز النواحي التي هي على الأغلب مستوطنات بشرية يغلب عليها الطابع الزيفي. لقد قامت بأعداد المخططات الأساســية للأنـــواع الثاني و الثالث و الر ابع كو ادر عر اقيــة فــي المديريسـة العامة للتخطيط العمز اني ووحداتها التخطيطي.ــــة فـــي المحافظات إلا ان الأخيرة لكثرتها ولقلــــة المعلومـــات

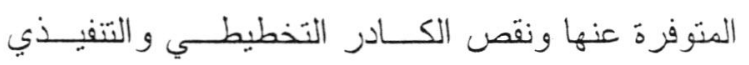
تعاني الكثبر من التخبط سواء في أعداد المخطط الأساسية او في عمليات التنفيذ لها مما أستدعى بالقيــام بحملة سميب بحملة نطويز النو احي في منتصف عـــام

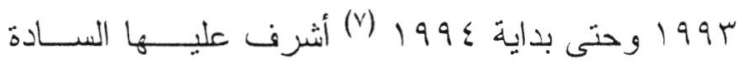
أعضاء القيادة و الوزر اء ومن هم بدرجتهم. وقد كشـت

هذه الحملة الكثير من المشاكل التخطيطية و التتفيذية. في هذا البحث، سننظر الــــى الخلفيــات للغايــة و المباديء الأساسية لإعداد التصاميم الأساسية للمــــن الصغيرة في العر اق ينبعه مناقشة الوحسـدات الاداريـــة و البلايات في العراق ومن ثم كيفية احســــاث البلديــات و المدن الصغيرة ومناقتة اعداد التصاميم الأساسية لــهـا

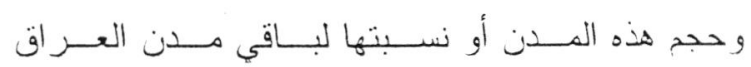
وتقنيماتها ومن ثم يليه اختبار لعمليات تتفيذ التصــاميح

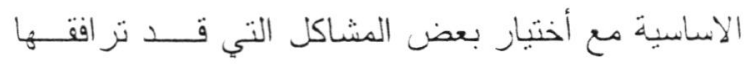

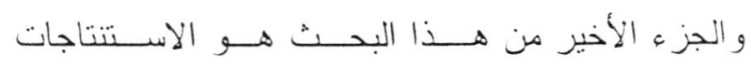

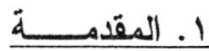

لا شك ان عملية التخطيط للهـــن هـــي عمليـة

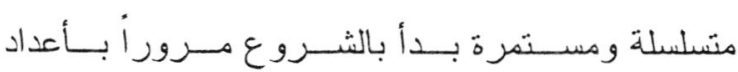

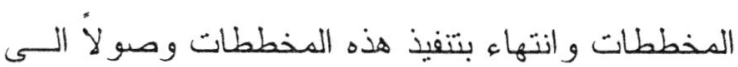
حالة أفضل لساكني هذه المدن. ولعدة أسباب فأن المدن الكبيزة و المتوسطة الحجم في العر اق قد حضيث بأهتمام لا بأس به ليس فقط مـن الجو انب التخطيطية و الفنية بالرغم من السلبيات التــي رافقتها و أنما ايضاً من الجو انب البحثية لغرض معالجة

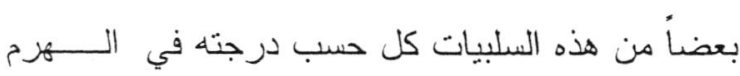
النسبي للحجم و الاهمية.

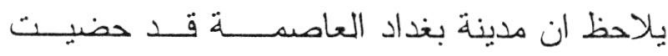

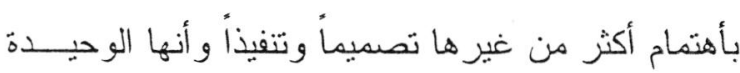
من بين المدن العر اقية تمتلك قانونأ لمخططها الأساسي نشر في الجريدة الرسمية (') ولها ادارة خاصة مرتبطة

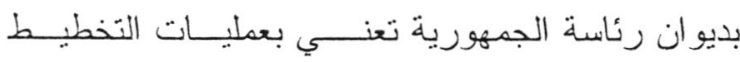
و التصميم و التتفيذ و التي هي أمانة بغداد التي تقوم ايضاً

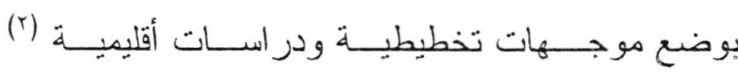
وبموجب تخصيصات مالية سنوية خاصة. أما المدن التي تلي مدينة بغداد من ناحية التـدرج الهرمي لحجوم المدن في العر اق فتقسم الى ثلاثة انو اع رئيسية هي: الاول : مر اكز المحافظــــات. النــاني: مز اكــز

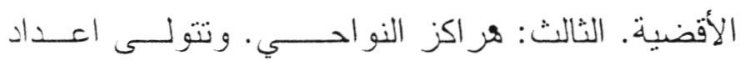

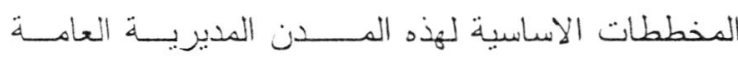
للتخطيط العمر اني و وحداتها التخطيطية (ץ) في مر اكز المحافظات اما عمليات التنفيذ لهذه المخططات ثقو بها بلدياتها من خلال مديريات بلديات المحافظــــة المعنيــة التابعة لمدبرية البلديات العامة في وز ارة الداخلية (؛). ان عملية وضع المخططات الاساسـية للمر اكـز الادارية كان على أربع أنو اع هي: 


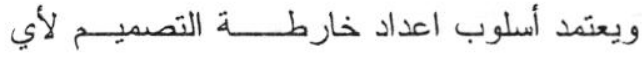

مدينة على حجم المدينة و المقياس المنبع في رســـــها، حسب خر ائط المسح الميداني المعد لها الذي غالباً مـــــا

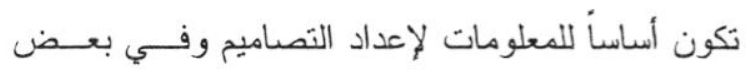
الحالات لا تشمل هذه الخر ائط المعلومات المطلوبة في

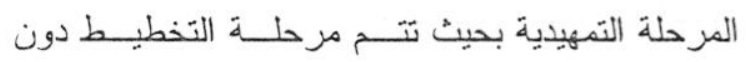

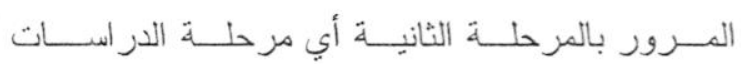

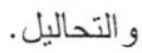
r-r الأطلر القاتوني وتنفيذ التصامبيح

ان الإطلار القانوني المعدــــول بموجبــهـ حاليــان

لإعداد وتتفيذ التصاميم الاساسية للمدن في العـــراق لا لا

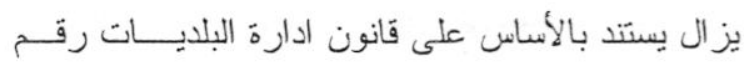
17 17 لسنة ؛ 97 (،وتعديلاته ونظام الطرق والابنية رقم

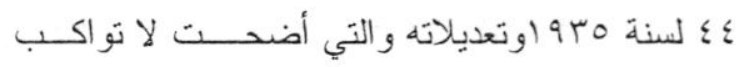
المتغير ات الكبيرة التي حصلت وما صدرمن فـــرار ات مجلس قيادة الثورة ذات العلاقة لدعم العملية التخطيطية عدا ما يخص مدينة بغداد.

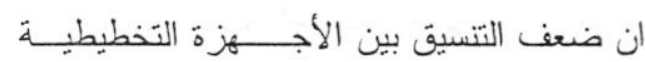

المركزية التيخ تشرفت على التخطيط الانمائي الثــــامل و الاجهزة التتفيذية المحلية مع فقدان حلقة مهمـــة مسنـ

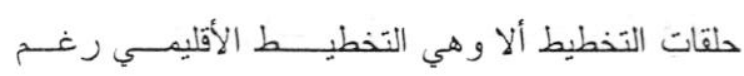
الدر اسات التي تقوم بها دائرة التخطيط الاقليمــي فـيـي

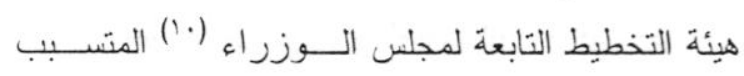
بالتالي الى ظهور مؤشر ات غير مرضية في العمليــــة التخطيطية و التصهيمية على مستوى الاعداد و التنفيذ .

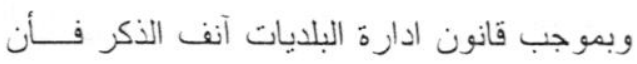
مهية اعداد التصاميم الاساسية وتنفيذها تقع على عـلتق

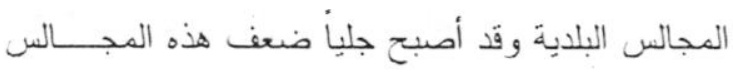
ادارياً وفنياً وعجزها التام في كلا الحالتين وما قر ار اتها إلا تصديقاً لقر ارات مركزية وأن سو وتنفيذ المخططات

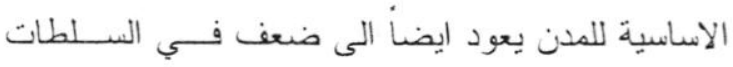
البلدية لضعف الكو ادر الهندسية و الفنية مما بيتزتب عليه
و الاستنباطات المتوخـــاة منـــه لتوحـــي الــى بعـــ

$$
\text { المقترحات و التوصيات. }
$$

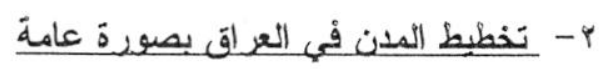
r- الحلقة التخطيطية وتخطبط المدن

ان تخطيط المدن هـــو أحــد حلقـات التخطيــط

الأنمائي الشامل بمستوياته المختلفـــة لوضـــع سياســة متكاملة ورسم السياسة المستقبلية للمدينة لا يمكـــن ان

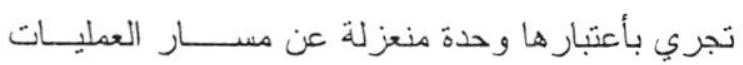
التخطيطية الاخرى له أهدافه ومبادئه الأساسية (^) إلانية أنه من الملاحظ هناك فجوة كبيرة بين السياسات العامة و المخططات الاساسية للمدن العر اقية بمختلف حجومهها وبين عملية التنفيذ لها في أرض الو اقع بصورة عامـــة ضمن حلقات التخطيط المختلفة بالإضافة الى الضعـف في بعض حلقاته الاخرى إلا ان هذه الفجوة قد تتوســـع الى حد كبير وقد تصل الى خد الانقطاع كلما صنغــــر

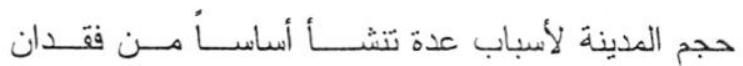

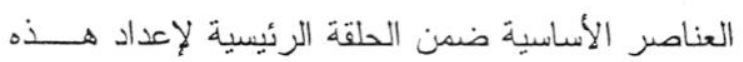

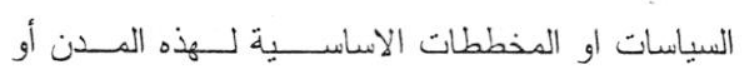
المسنوطنات بالإضافة الى ان عملية التنفيذ لها تتطلــبـ ادارة ومتابعة ميدانية بكو ادر متخصصة وكافية وقريبة من موقع التنفيذ. r r اعداد التصاميب الاساسية للمدن

يتم اعداد التصاميم الاساسية للمـــدن العراقيــة على عدة مر احل هامة متسلسلة ويتوقف مدى شــــمول

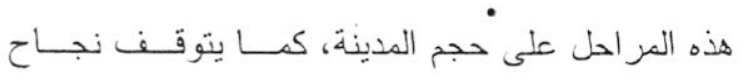
عملية اعداد التصاميم على مدى الاســنفادة مــن كـل مرحلة لذدمة المر احل التالية لتحقيق الأهداف المتوخاة

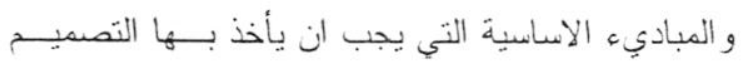

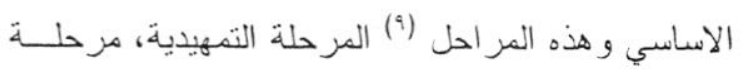
الدر اسات و التحاليل وثم مرحلة التخطيط لينت الاعـــلان عنه و التصديق عليه، ومن ثم التتفيذ. 


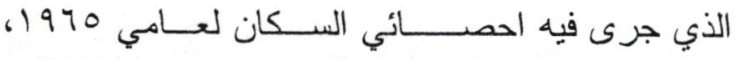
19VV لإعداد المخططات الاساسية للمدن الرئيســـية و المــدن المتوسطة و الصغيرة الحجم في العر اق مما أحذث خلاذ

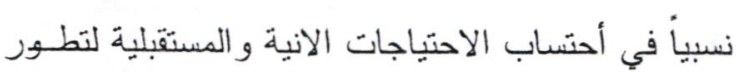

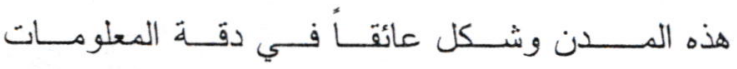
و الاحصاءات السكانية التي يجب اعتمادها في هر احسل عمليات وضع المخططات الاساسية للمدن. فيكون هـذا الخلل النستبي كبير أ للمدن الصغيرة ، وبالتــالي أوجـــ

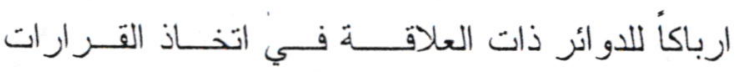

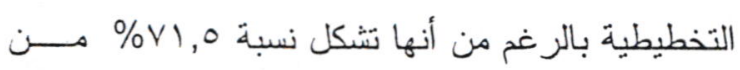
مجموع هذه المدن. و على أي حال فأن البلدية تحدث في مركز كــلـ من المحافظة و القضاء و الناحية مهوا كان غدد نفوســـه وفي القرى التي لا يتجاوز عدد نفوســـــا ثلاثـــة آلاف

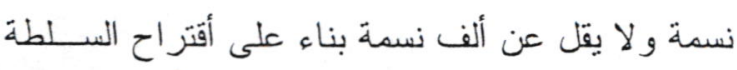
الادارية وتو افر الامكانات المالية ومو افقة الوزيز وتبقى

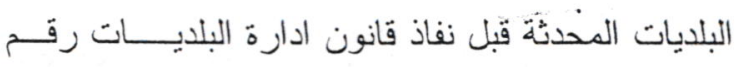
170 السنة \& 197 في القزى التي بيقل عدد نفوسها عن

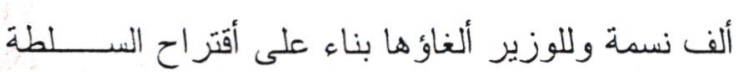
الادارية (r) (1).

\section{r-r تصنيف البلديات وتحديد المدن الصغيرة}

تصنف البلديات على أساس عدد النفوس وفـــق آخــر أحصاء رسمي عام كالتالي (؛؛ ('): - أمانة بغداد من الصنف الخاص. - ـ بلديات الموصل، البصرة وكركوك من الصنف الممثاز . - بلديات مر اكز المحافظات الاخرى و البلديات التي لا يقل عدد نفونـــا

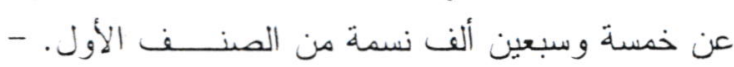
البلديات التي لا بقل عدد نفوسها عن خمسة عشر ألـــ نسمة من الصنف الثاني. -البلديات التي لا بِقل عـــدن نفوسها عن خمسة آلاف نسمة من الصنف الثـالث. -
تغيير ات جوهرية على الهيكل العام لتلك المخططــــات ومهام تنفيذها.

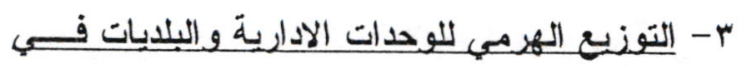
العزاقة

r- التوحدات الادارية في العرلق

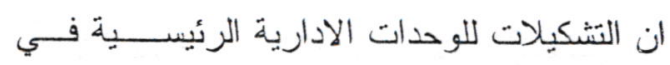

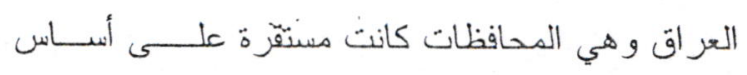

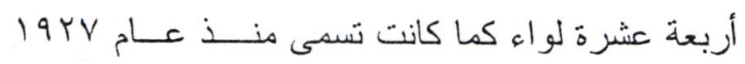

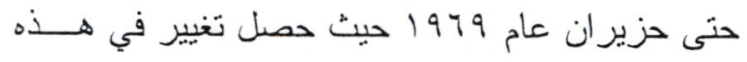

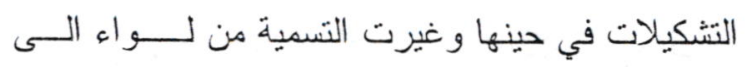

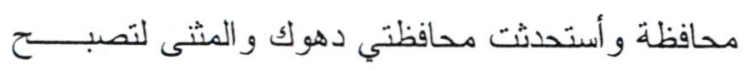
ست عشرة محافظة وحصل تغيير في تسميات بعـــ وض المحافظات وفي مساحات محافظتي نينوى و القادسـية فقط و التي اســتقطع منــــا المســاحات للمدــافظتين

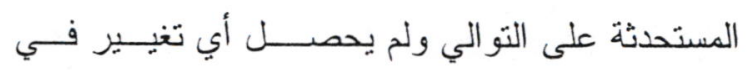
مساحات المحافظات الأخرى. وفي عام 19AV نتم استحداث محافظتي صـــلاح الدين و النجف باستقطلاع مســـاحتيهما مــن محـــافظتي بغداد، التأميم الاولى وكربلاء الثانية، رافق ذلك تغيـيراً

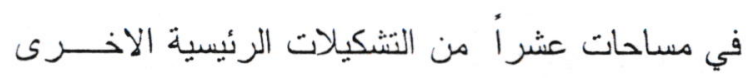
بضمنها المحافظتين المستحدثة (')' وبطبيعة الحال فـلنت هذه التغييرات تتسحب الى التشكيلات الاصغر حجمـــن وهي الاقضية و النواحي. وقد أستقز هذا الحال على ما هو الى يومنا هذا مع بعض التغييرات البسـيطة التـي لهي

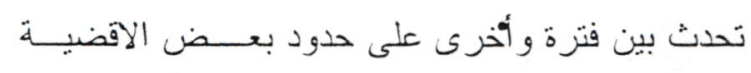

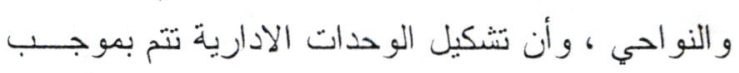

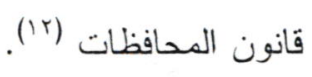
r-r تحدبد البلايسات و المدن العر اقية

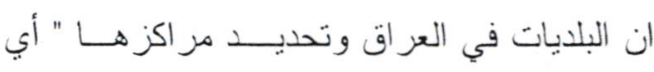
المدن" بمختلف أنو اعها و أحجامـــــا تنبـــع التشــكيلات الادارية كما سيأتي عرضدهولو لاحظنا الفترات الزمنية

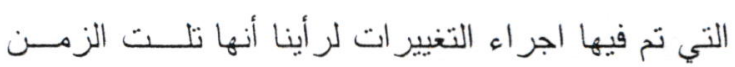


بلدياتها من الصنف الر ابع و الجدول رقتـــ (1) يبيـنـ توزيع بلديات محافظات العراق حسب أصنافها وحسب

التغييرات الحاصلة عليها.
البلديات التي يقل عدد نفوسها عن خمسة آلاف نســمة من الصنف الرابع.

إذا وبغض النظر عن النظريات المختلفة عن أحجــــام المدن فأنه و لأغر اض هذا البحث يمكن تحديد المـــــن الصغيرة في العراق بأنها المدن او القصبات التي تكون

جدول رقم (1) - جدا

توزيع بلديات المحافظات في العراق حسب أصنافها (10)

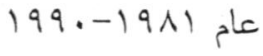

\begin{tabular}{|c|c|c|c|c|c|c|}
\hline \multicolumn{7}{|c|}{ صنف البلديات } \\
\hline المجموع & رابع & ثالث & ثاني & أول & معتاز & المحافظة \\
\hline 17 & $1 \cdot$ & $\varepsilon$ & 1 & 1 & - & دهوك \\
\hline rr & 11 & 9 & $\varepsilon$ & - & 1 & السليمانية \\
\hline$r \varepsilon$ & 10 & V & 1 & - & 1 & أربيل \\
\hline דו & Yo & $\wedge$ & r & - & 1 & نينوى \\
\hline $1 \varepsilon$ & 11 & r & - & - & 1 & التأمِِم \\
\hline r. & Ir & r & r & 1 & - & صلاح الدين \\
\hline$r 7$ & Ir & 1 & 1 & - & 1 & ديالى \\
\hline rr & $1 \varepsilon$ & 1 & r & - & 1 & الأنبار \\
\hline V & $\varepsilon$ & 1 & 1 & - & 1 & كربلاء \\
\hline 1. & 1 & r & 1 & - & 1 & النجف \\
\hline 17 & 1 & 1 & $r$ & - & 1 & بابل بابل \\
\hline 10 & $\wedge$ & $\varepsilon$ & r & - & 1 & القادسية \\
\hline 11 & $\wedge$ & 1 & 1 & 1 & - & المثنى \\
\hline$r$. & $\wedge$ & 9 & r & - & 1 & ذي قار . \\
\hline IV & ir & r & 1 & 1 & - & و اسط \\
\hline $1 \varepsilon$ & 9 & r & 1 & - & 1 & مبيسان \\
\hline 11. & 0 & $\varepsilon$ & $\wedge$ & - & 1 & البصرة \\
\hline$\wedge$ & 7 & - & r & - & - & بغداد \\
\hline TrV & 191 & $\vee \wedge$ & $\leqslant 1$ & $\varepsilon$ & 14 & المجمو ع \\
\hline
\end{tabular}

المصدر : وز ارة الداخلية - مديرية البلديات العامة - مكتب التخطبط و المتابعة 
وبحلول عـام 1911 وحتـى منتصسـف أستقرت اصناف البلديات كما في الجدول رقم (1) ولــم يحصل عليه أي تغيير جذري حتى اليوم سوى انتقـــال بعضها الى الصنف الثالث. ع - المدن الصغبرة في العراقى ومخططاتهيا ؛ - المدن الصغيرة في العراق

لقد تم استنباط جدول لأغر اض هذا البحث مبنيـــا على أســاس التشــكيلات الإداريــة الحاليــة ونتــائج

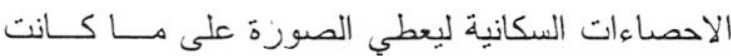

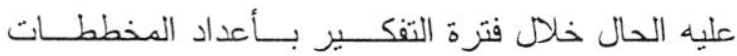
الاساسية للمدن الصغيرة حيث اتضتح انه بالر غم مـــن التغيير ات سالفة الذكر لم يكن لها تأثير جوهري علــى النتائج المتوخاة منها، حيث ان اعـــداد البلديــات فــي العر اق لم يحصل عليه تغيير كبير بموجب التغيــير ات

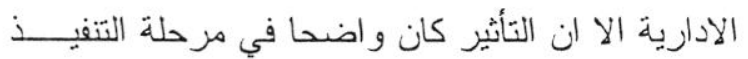
لهذه المخططات بسبب انتقال السلطات الاداريــة مــن تشكيل الى آخر كما سبق ذكره في (r • (). ونشير هنا الى ان الجدول المذكور سيستثي مز اكز المحافظــــات (جدول رقم r) (ب).

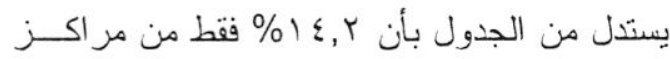

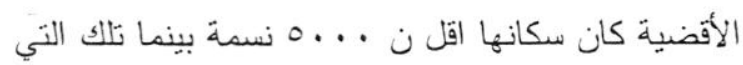

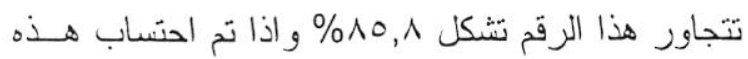

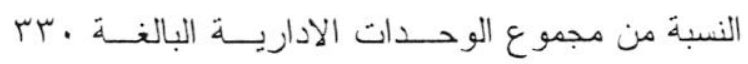

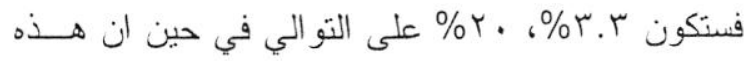
النسبة نكون معكوسة تثزيبا في حالة مر اكز النو احـــي

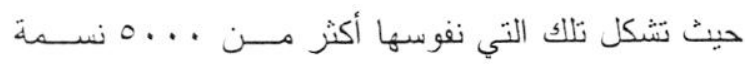

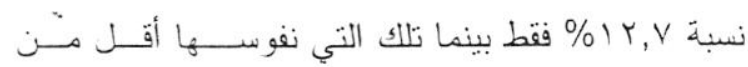

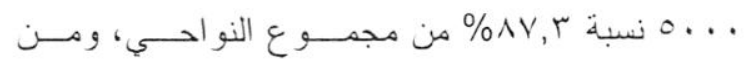

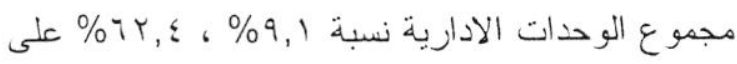

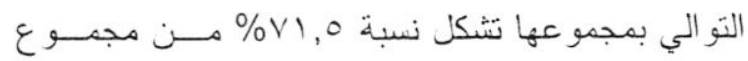
الوحدات الادارية كما ذكرنا سابقا. (r.r. (Y).
من الجدول رقم (1) يتضح لنا انه منذ صــــدور قانون ادارة البلديات فأن عشـــر مــن مــدن مر اكــز المحافظات ازداد عدد سكانها ليصبح صنفها ممتاز بدلا من الصنف الأول بينما لم تتخير أصناف أي من بلديات

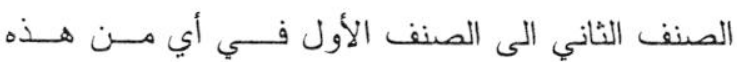
المحافظات بينما حافظت مر اكـــز لأربـــع محافظــات المتبقية على صنفها الأول.أما بلديات المدن من الصنف مراح

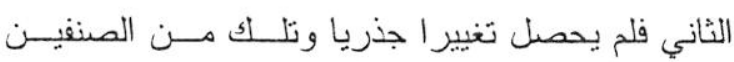
الثالث و الرابع فأن التغيير الرئيسي الذي حصل هو في ازدياد اعدادها نظر ا إحداث وحدات جديدة يترتب عليه

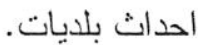

\section{r-}

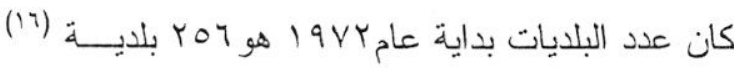
أي انه كان هناك حو الي ع لهزكز اداري لم يحدث فيـها بلدية نشكل نسبة اكثر من rr\% يقضي القانون اعـداد خر ائط حدود بلدية لها لغرض احداثها تلك هي التـــي سكانها ريفيون. وحتى ذلك الوقت فأن المديرية العامــة للتخطيط و الهندسة قد أعدت مخططات 79 مدينة فقـ ط أي ما يعادل حو الي (IV)

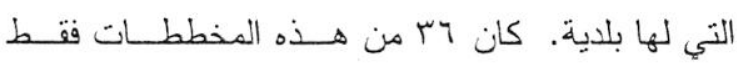
مصدقا تصديقا نهائيا أي ما يعادل .0\% منها. ارتفع عدد البلديات في عــام 19VV الــى بr

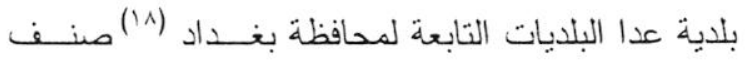

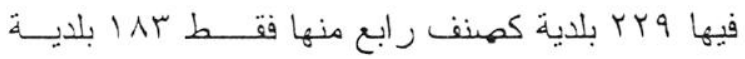
بمكن اعتبار ها من هذا الصنف وتشكل أكثر من 07 من مجموع البلديات، أما البلديات الاخرى أي 1؛ بلدية فأن بـ منها كان يجب اعنبار ها من الصنف الثـــالث و ؛ كن الصنف الثاني. هذه المتغبرات نتسحب علــى البلديات من الصنفين الثاني و الثالث إلا أنـــــا تنطـــابق و القانون في بلديات الصنفين الاول و الممتاز . 


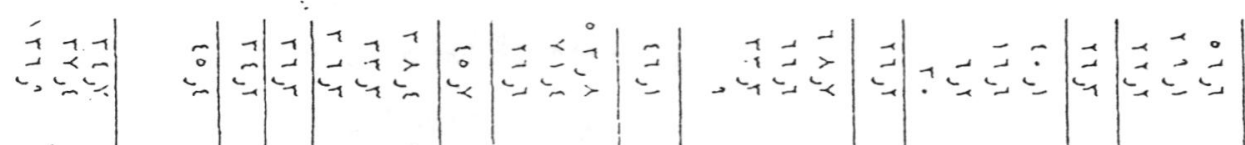

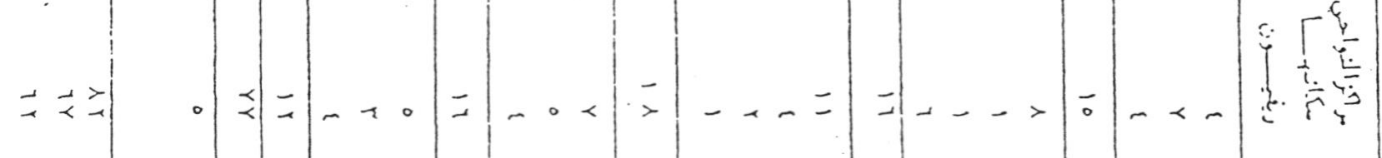

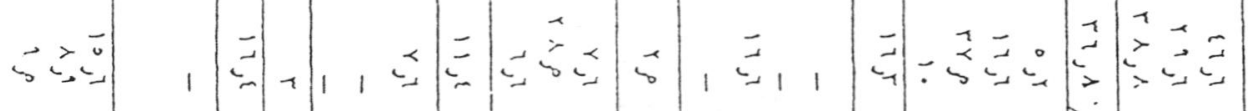

$=\int_{-1}=|\quad| \quad \mid$

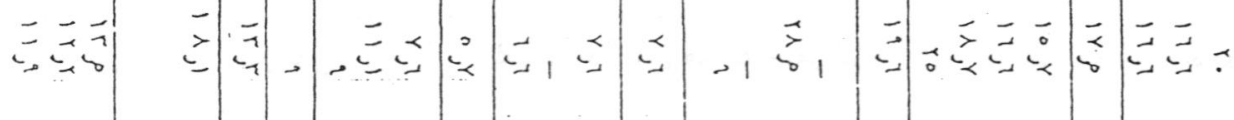

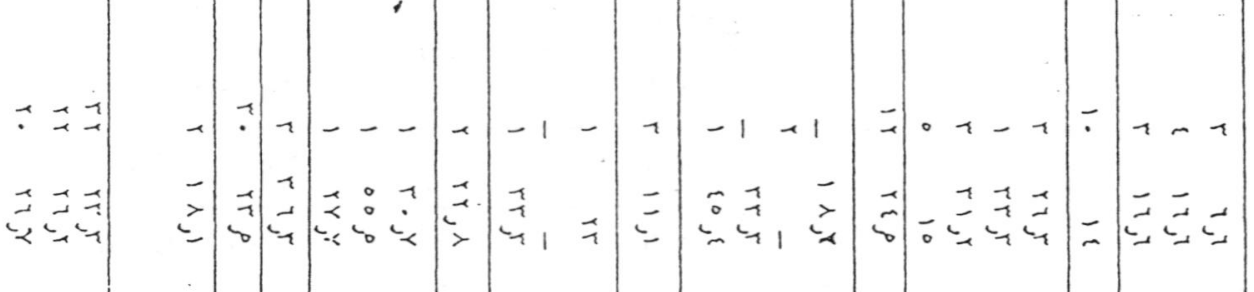

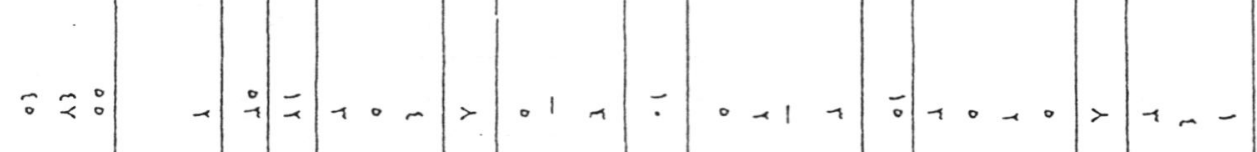

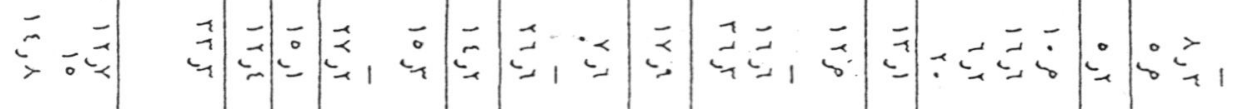

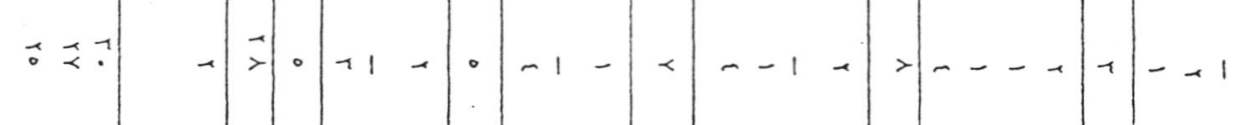

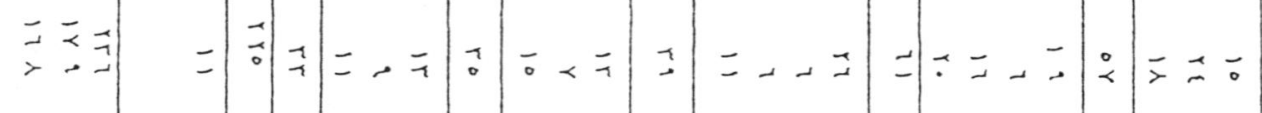

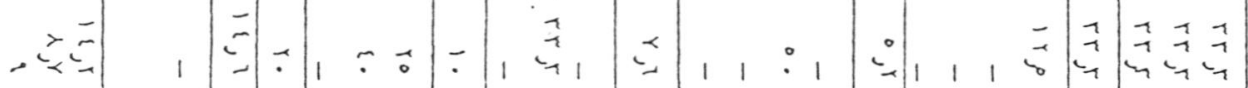

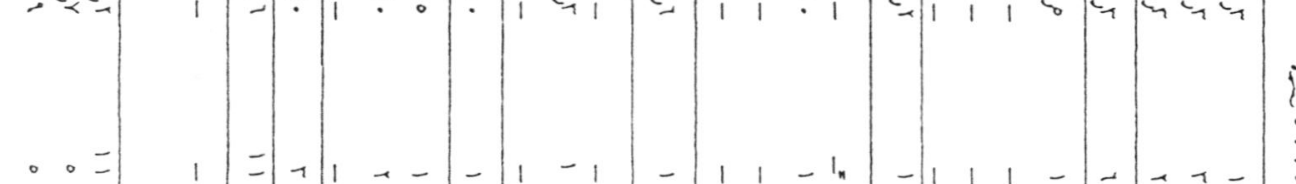

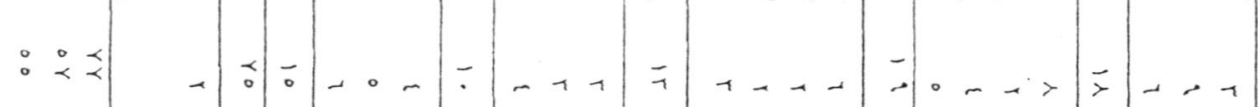

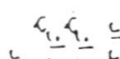

S.

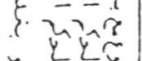

EF

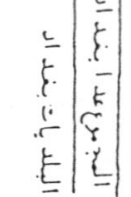

$\ddot{t}+5$ $1=-$

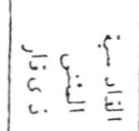
$1=\bar{z}=1$

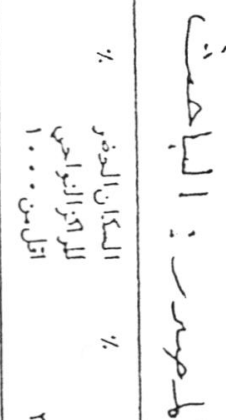

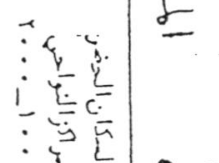

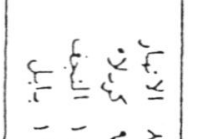

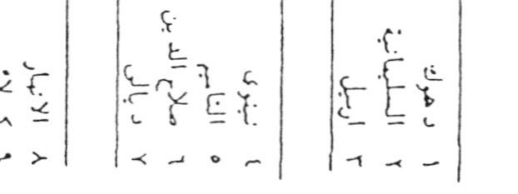

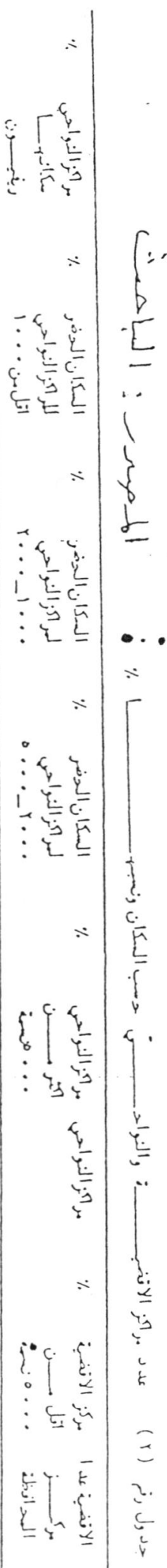


ويمكن تقسيح مر اكز النواحي كما في الجدول رقم

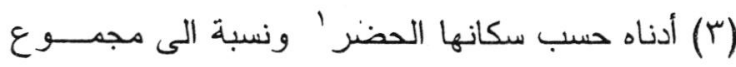
مر اكز النواحي و المجموع العام للوحدات الادارية.

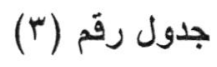

سكان مراكز النواحي من الحضر في العراق ونسبتها لمجموع هذه المراكز

ومجموع الوحدات الإدارية

\begin{tabular}{|c|c|c|}
\hline النسبة \% من مجموغ الوحدات & النسبة \% من مجموع مر اكز & سكان هراكز النواحي \\
\hline 17,74 & $r r, r$ & $0 \ldots-r \ldots$ \\
\hline $9, \mathrm{~V}$ & 15,0 & $r \ldots-1 \ldots$ \\
\hline $11, r$ & 10,1 & أقل من ... \\
\hline$r \varepsilon, \wedge$ & $r \varepsilon, V$ & لا يوجد سكان حضر \\
\hline $4 r, r 4$ & $A V, 1$ & المجموع \\
\hline
\end{tabular}

المصدر : الباحث

'معيار السكان الخضر اعتمد معيار التعداد العام للسكان للسنوات

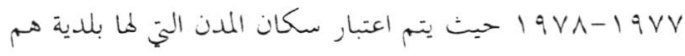
سكان حضر وغيرهم ريفيون. 
بصورة منو ازية كلما أمكن مـــع مر اكــز المحافظــات و الاقضية لإمكان الاستفادة من الاســتثمار ات للخطـ طـ الخمسية وخطط الاستثمار ات لسنو ات ما بعســـــــورة

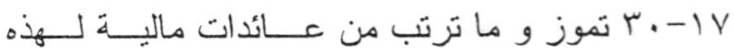
الخطط بعد تأميم النفط عام بVY9 19 وكما أطلق عليــــا صحوة المخططين العر اقيين من سباتهم العميق (19). ع - r حدود البلابيات و اعداد التصمبيح

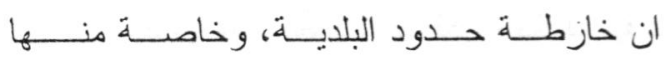
المستحدثة، و غالباً ما تكون هذه للمـــدن او القصبــات الصغيرة او الجديدة تعد على أساس' أحتساب منـــــاحة

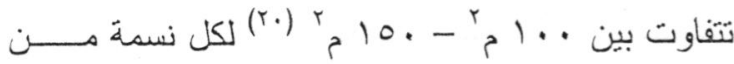
السكان في المستوطنة البشرية المعينة كمساحة عامــــة لتلبي المتطلبات و الاحتياجات العامة لمختلف الخدمسات و الفعاليات المستقبلية و المتوقعة لتللك المستوطنة بشــكل عام وذللك حسب التوزيع الجغر افي للفعاليات الحاليــــة وموقع المسنوطنة، ويشكل هذا على وجه الخصــــوص المساحة الافتز اضية للمخطط أو التصميم الاساسي لـــا بغض النظر عن الدراسات و الموجهات الاقليمية فــــي أغلب الأحيان. ويتم ذللك بموجب خارطة مسحية أوليــة للمنطقة غير و اضحة وبمقيــاس رســم تختلــف مسن مستوطنة الى أخرى وتغطي رقعة جغر افية لا تتسع في

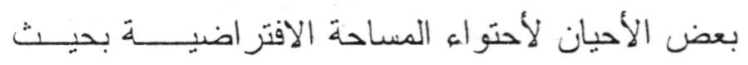
تظهر المنشآت القائمة في المستوطنة فقط وبعضا مــن

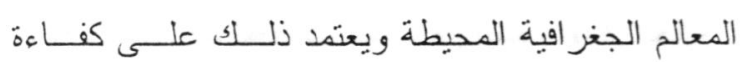

$$
\text { المساح وتوجهه التخطيطي. }
$$
وكثير ا ما تفتقر هذه الخر ائط الى المعلومات التي يتطلبها اعداد مخططات التصميم الأساسي وبالر غم من ذلك فأنها تعنمد من قبل المخططين بأعتبار ها خارطــة الأساسمase map ويلعب ضعف الكادر التخطيطي و المعلوماتي في المؤسسات البلدية المحلية و المؤسنـلت

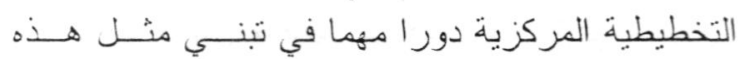

فيما عدا محافظة بغداد وحيث ان لها حالة خاصة

من الناحية الادارية بالنسبة لمركزها وبصورة عامــــة فأنه من الملاحظ بالنسبة لمر اكز الاقضية التي ســكانها

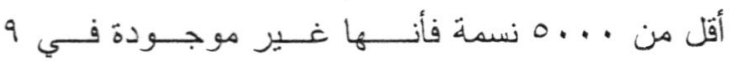
محافظات بينما هناك مركز قضناء و احد فــــي خمـس سـ محافظات وركزين في محافظتين فقط ومحافظة فيـــها ب مر اكز أقضية وهي تشكل نسب قليلة بطبيعة الحال. بينما نجد بأن جميع مر اكز النواحي فـــي أربــع محافظات هي دهوك، كربــلاء ، المثنـى وميســان و

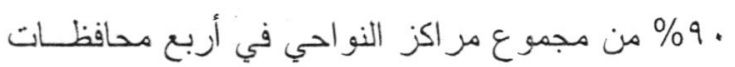

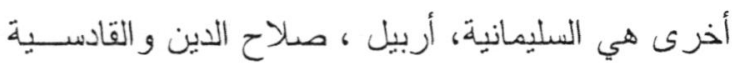

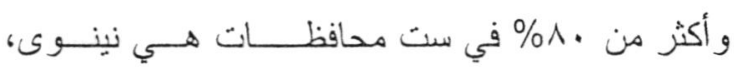

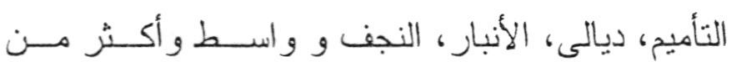

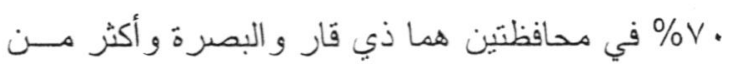

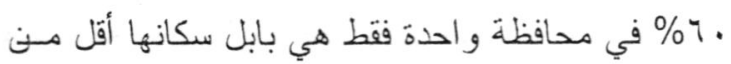

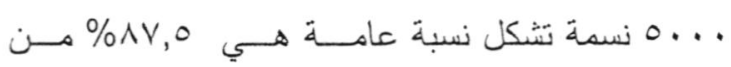
مجموع مر اكز النواحي في العراق.

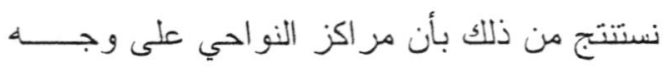
الخصوص هي أقرب لأن نكون مدن صنــيرة وكمــا يطلق عليها في كثير هن الأحيان مصطلح قصبــات أو أنها مستوطنات بشرية † كان من الممكــن ان يكــون در اسة نحوها او تطوير ها و وضنع سياساتها المسـتقبلية على أساس تصاميم هيكلية مستخدة الى در اسات اقليميـة

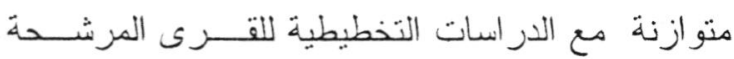

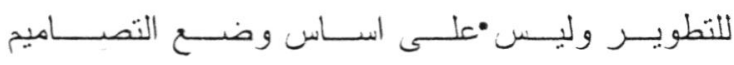
و المخططات الأساسية لها بغياب در انســات موجهـــة للانمو و التطور بصورة عامة الا ان التوجه كــان فــي نهاية السنينات بأن توضع مخططات لكافة القصبـــــات ' القصبات هي مر اكز الاقضية او النواحي التيّ يتراوح سكانا بين

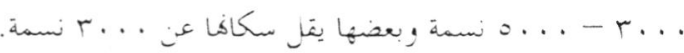

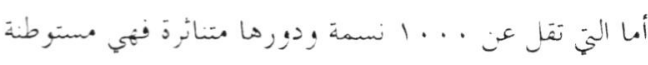


التكنولوجية. كذلك فقد ألغي الفرع الحضري في القسـم المعماري من الجامعة التكنولوجية بعد العام الدراسـيسي 9 -9 9 9عد خمس سنو ات من تشكيله.

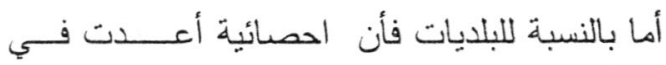

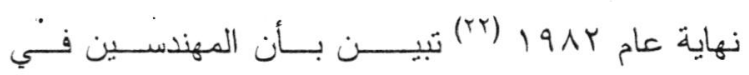
المحافظات و أغلبهح من خريجي الهندسة المدنية، حيـث لايوجد من المعماريين سوى ثلاثة في محافظة التــأميم و و احد في كل من الأنبار وبابل و القادسية، والآخــون

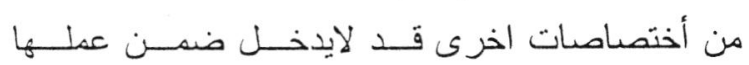
موضو ع تخطيط ألمدن.

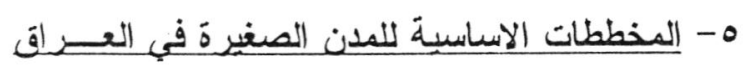

\section{وتنفيذها}

- - أعداد التصميح الاساسي

بعد اعداد خارطة بلدية لتلك التي ثم احداثها فــي المستوطنة مهما كان حجمها ويتم تصديقها بعد اعلانـها Master plan يتوجب اعداد مخطط او تصميم اساسي بأعتماد الخارطة المسحية التي تم اعداد خارطة حسدود لـوني البلدية بموجبها او خارطة للمنشآت فـــي المســوطنة.

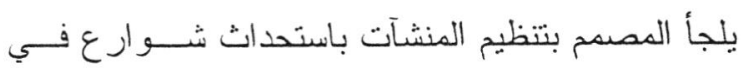
المنطقة القديمة واستحداث منـــاطق توســـع مســتقبلية تصمم على أساس المعلومات السكانية كذلك انــــداث مناطق الخدمات و المنافع العامة المختلفـــة كــالمدارس و الحضانة و رياض الاطفال و المستو صفات و المبــــي الحكومية و الحدائق العامة وبطبيعة الحــــال الشــــوارع الرئيسية و الفرعية بمعزل عــن السياســات الاقليميــة

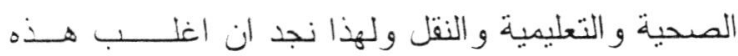
المخططات تبقى حبر ا على ورق لبس إلا (rr).

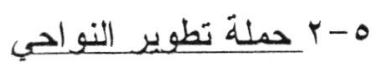

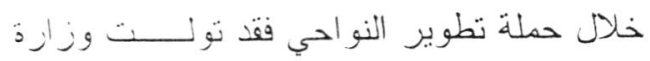

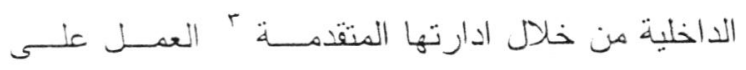

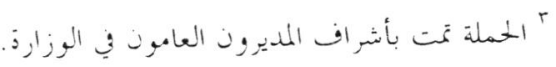

الخز ائط المسحية لإتصام عملية التصميم وفيما بعد فـيـي عملية التنفيذ و ما ير افقها من تخبطات.

\section{ع - r الكو ادر التخطبطية و التنفيزية}

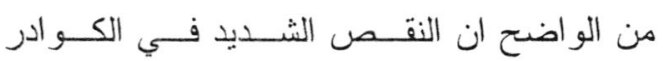

التخطيطية و التنفيذية له الأثر الكبير على سير العمليــة التخطيطية و اكتمال حلقتها المتسلسلة و على سبيل المثال فأن المديرية العامة للتخطيط العمز الني لم تكن تخصص ولى اكثر من مهندس او مخطط و احد لكل محافظة ليقــــوم بإعداد المخططات الاساسية و التفصيليـــة لكــلـ مــدن وقصبات تلك المحافظة خلال العقدين ونيف المساضيين وفي بعض الأحيان يقوم مهندس او مخطط و احد بـــــا الو اجب لمحافظتين عدا محافظتي نينوى و البصرة حيث يخصص مهندس لمركز المحافظة ومهندس او مخط ط لقصباتها حيث كان كادر هذه المديرية يتكون مسن 11

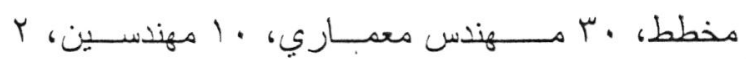

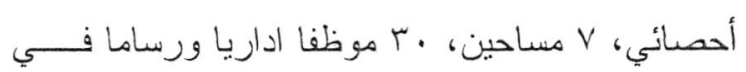

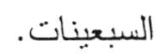

وقد نتاقص هذا العدد هنذ بداية الثمانينات لعـــــدة اسباب وان احد هذه الأسباب هـــو تشــكيل الوحسـدات

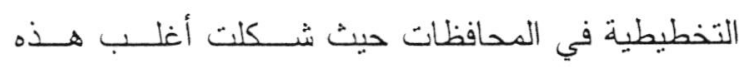
الوحدات من كادر تلاك الدائرة المركزية حيث نـــى ان كادر ها الحالي بما فيه كادر الوحــــدات التخطيطيــة لا لا

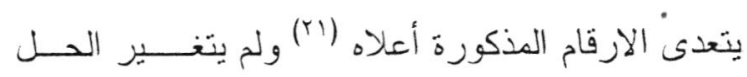
بالنسبة للأعداد للمخططات بصورة رئيسية الا في حالة احتياج الدائرة الى للايفادات الكثيرة للمخططيسـن لســد النقص في اعداد المسح الميذاني. وكان لإنشاء كلية التخطيط في العــــام الدر اســـي

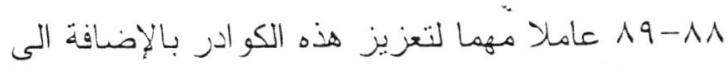

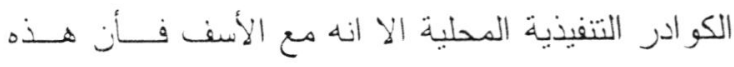
الكلية قد ألغيت وهي في المهد بعد فصل دراني واحـد من مباشرتها و الحق طلابها الى الصفوف الاولى مـــن

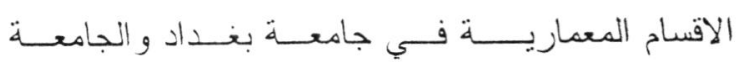


تطوير (•r) ناحية المتوسطة الحجم في النصف الثاني

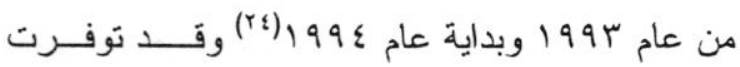
المعلومات التفصيلية لأكثر من •0\% منها و التي تبيـن النسب الكبيرة من أعمال التنفيذ التي لم تكن منفذة سابقا

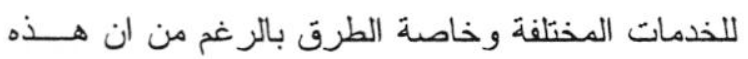
النسب تشكل نسب ضئيلة مما هو مصمـــم لــها فــي التصاميم الاساسية تصل الى. • (\% في بعض الــلات ولا تتجاوز 10\% - . . \% في الحالات الاخرى. لقد تم خلال هذه الحملة ايضا القيام بأفراز قطع أر اضي لمناطق سكنية جديدة ليضيف هذا نسبا جديــدة للخدمات الغير منفذة فيها. وقد أجرت المديرية العامـــة للتخطيط العمر اني العديد من التعديلات على تصـــــاميم الكثير من مر اكز النواحي في السنوات الثلاث الماضية

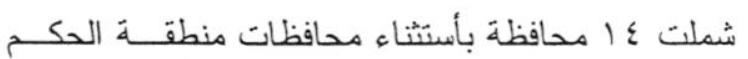
الذاتي. ويجدر بالاشارة الى ان حملة تطوير النواحسي شملت مر اكز النواحي التي يزيد سكانها عـــن .... نسمة.

\section{ه-r نسب تنفيذ تصامبيم المدن الصغيرة}

لقد نت زيارة ما مجمو عه (^^) مركز ناحية من

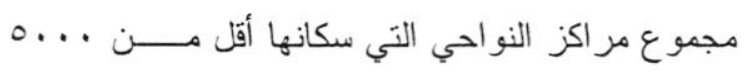
نسمة في مختلف محافظات القطر بأسنثناء محافظـــات

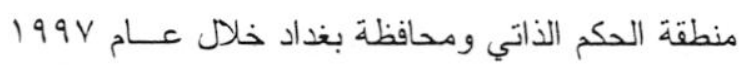

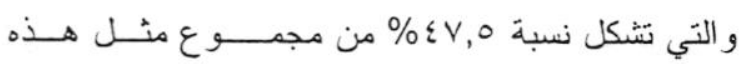

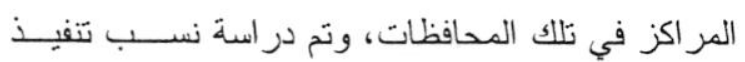
التصاميم الاساسية للكســـتعمالات المختلفـة وحسـبـ الجدول رقم (؛) وبالتعاون مع مهندسي المديرية العامة للتخطيط العمز اني و وحداتها: التخطيطية التابعة لوزارة الداخلية. 


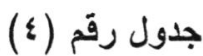

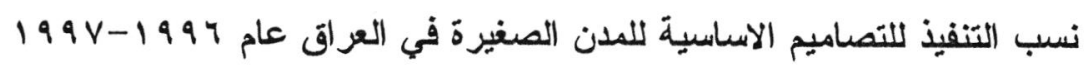

\begin{tabular}{|c|c|c|c|c|}
\hline تنفيذ التصاميّ & 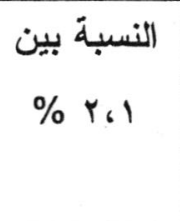 & 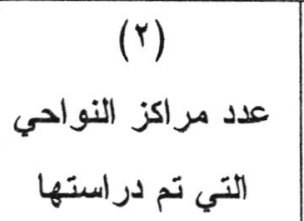 & 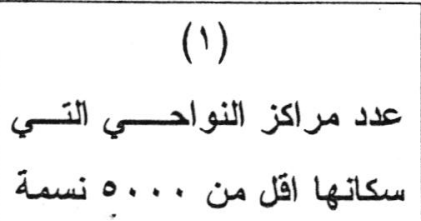 & المحافظة \\
\hline iv & $\varepsilon V$ & $\wedge$ & IV & نينوى \\
\hline 10 & $\varepsilon$. & r & $\therefore$ & التأميم \\
\hline $1 T$ & $\varepsilon$. & 1 & 10 & صلاح الدين \\
\hline 11 & 0. & $\Lambda$ & 17 & ديالى \\
\hline Ir & 0. & v & $1 \varepsilon$ & الانبار \\
\hline 11 & 0. & r & $y$ & كربلاء \\
\hline $1 \varepsilon$ & 7. & $r$ & 0 & النجف \\
\hline 19 & or & $\varepsilon$ & v & بابل \\
\hline IY & 0. & 1 & Ir & القادسية \\
\hline 1. & or & $\varepsilon$ & V & المثنى \\
\hline 11 & ry & 0 & 11 & ذي قار \\
\hline 17 & $\leqslant 0,0$ & $\varepsilon$ & 11 & و اسط \\
\hline $1 \cdot$ & 00,0 & 0 & 9 & ميسان \\
\hline IV & 0. & $\varepsilon$ & $\Lambda$ & البصرة \\
\hline $1 \varepsilon, \varepsilon Y$ & $\varepsilon \vee, 0$ & 71 & $1 \leqslant r$ & المجموع \\
\hline
\end{tabular}

المصدر : الباحث بالتعاون مع مهندسي المديرية العامة للتخطيط العمر اني

الصغيرة و التي تشترك فيه كافة المحافظات الاخــــرى

كما هي في مجمو عتي المحافظات و التي تضم الاولــى

محافظات القادسية، المثنى و ذي قار ، حيث يهبط فيــها معددل تنفيذ التصاميم للمـــدن الصغــيرة الــى 1/ وخاصة محافظة المثنى، وتضم الاخــــرى محافظــات

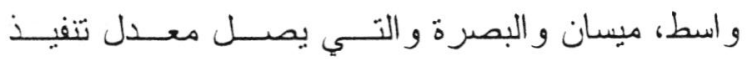
تصاميم المدن الصغيرة فيها الى حو الي ؛ ؛ \%
الصغيرة تنل عن نسب التنفيذ للمدن ومر اكز النو احسي لـي

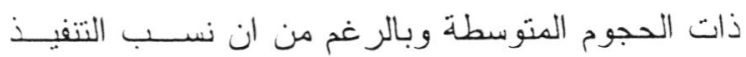

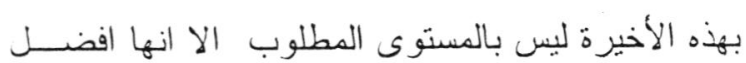

يتضح بأن نسب التتفيذ للتصاميم الاساسية للهــدن الصنغيرة في مجمو عتي المحافظات التي تضم نينـــوى،

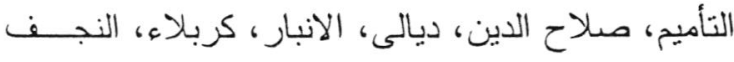
وبابل بحدود 17 \% كمعدل عام وقد ترتفع في بعسض

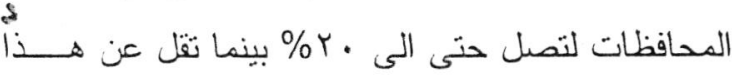

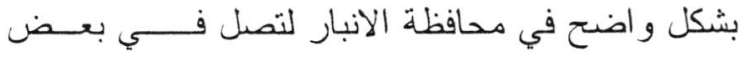
الحالات الى • (1\% و أقل من ذلك في حالات أخرى وقد يرجع السبب في ذللك الى كبر مساحة هذه المحافظـــــة عن المحافظات الاخرى و المسافات الطويلة بين مركـز

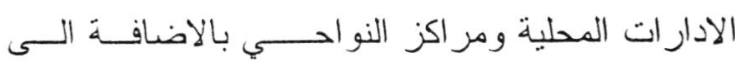
الضعف العام لمستويات تتفيذ التصاميم الاساسية للمدن 
r. . عدم التر ابط بين التخطيط الاقليمي و التخطيــط

الحضري وفقدان الحلقة بينهما وبين التخطيـــ

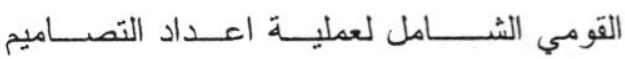

الاساسية.

ع. . ضنعف الكوادر التخطيطيــــة و التنفيذيــة فــي

الادار ات المحليــة وخاصـــة فـــي المر اكـــز

الصغيرة و النقص الشديد في كو ادر الـــــــيئات

و المؤسسات التخطيطية المركزية.

๑. ·الضتعف في الأطار العام للتخطيط في العـــراق

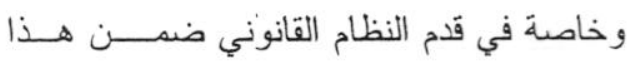

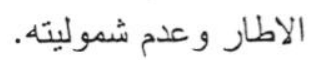

- التوصبيات -

وبشكل عام فأنه تظهر بعــــ الاحتياجــات العامــة

لاصلاح الحال بمكن تلخيصه بما يأتي:

- الحاجة الى ايجاد استر اتيجيات بصورة مخططسات

هيكلية او اقليمية و التي يجب ان نشكل جزءا مــن

$$
\text { اطار التخطيط الانمائي الشامل. }
$$

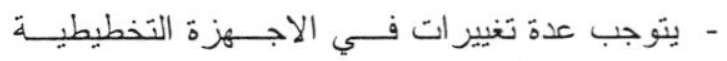
بهدف تكامل العملية التخطيطية سواء كان ذلك في المستوى المركزي او المحلي. - النظام القانوني للتخطيــــ الحضـــري و الاقليمــي يحتاج الى اعادة نظر بصورة شاملة و ايجاد قانون موحد للتخطيط في العر اق بشمل كافـــة عنــاصر الحلقة التخطيطية.

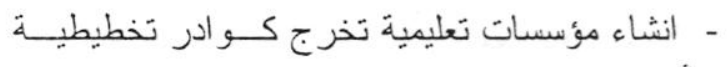
بمستوى الدر اسات الاولية وكو ادر مهنيـــة ســـاندة

$$
\text { لتلبي الحاجة الى مثل هذه الكو ادر. }
$$

- وبالتالي ليمكن ليس فقط من اعداد مخططات قابلة للتنفيذ و أنما أمكان الســـيطرة و المتابعـــة الفعالـــة لعمليات تنفيذها ايضا و التي يجب ان تكون امتـدادا
من الاولى و التي لم تظهر في أي منها حالة يمكــن ان ترقى في نسب التنفيذ الى أكثر من .r\%. ويمكن القول بأن هناك تدرج هرمي في مسـتويات

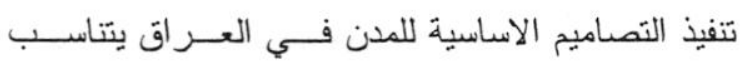
طرديا مع حجمها. وقد لوحظ ايضنا ان هنالك علاقــة عكسـية بيـنـن المسافات من مز اكز المحافظــات او الادارات البلديـــة المحلية وبين المدن الصغيرة مع نسب التتفيذ من جهـة وبين مساحة المحافظة و عدد المدن الصغيرة فيها مــن جهة أخرى. وفي هذا المجال بمكن الاستعانة بالخر ائط

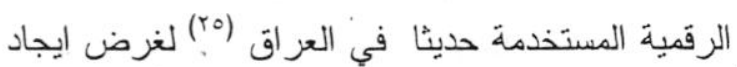
مثل هذه العلاقات بصورة أدق. 1- الأسنتتاجات

يتضح لنا بأن نسبة كبيرة من التصاميم الاساســية التي أعدت للمدن الصغيرة في العراق و التي بحد ذاتـها

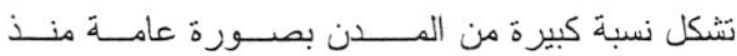
السبعينات لغرض النهوض بها من الطابع الريفي الــى الطابع الحضري لم ينفذ منها الا بمســــتويات ونســبـ منذنية جدا و أصبحت هذه المخططات الموجه للسياسات

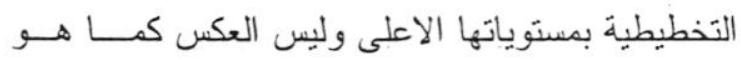
معمول به في الحلقة التخطيطية وهـــا ينطبـق علـى

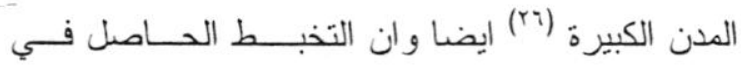

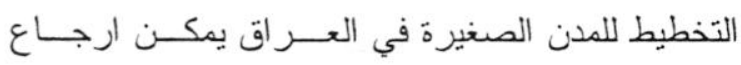

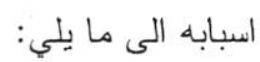
1. الضعف و الغقص في المعلومات و المســـوحات المختلفة عن تلك المدن او القصبات.

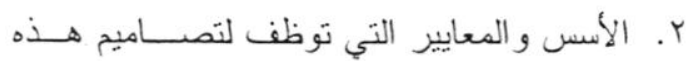
المدن يتم على أساس انها ذات كيان حضــريّ بالر غم من ان أغلبها هي مستوطنات ضغــيرة لا تشكل أغلبها أصغر وحدة حضرية ويغلــبـ عليها الطابع الزيفي. 
اليونانية و المركز القومي للأستشـــــار ات الهندســية و المعمارية 19V0.

7. تقريز " التصميم الأساسي لمدينة بغــداد " شــركة

$$
\text { بولسيرفيس البولونية مصدر سابق. }
$$

V. تتفيذا لأمر السيد الرئيس القائد و بتطوير نواحسي لـي القطر و الاشر اف المباشر عليها من قبـــل الســـادة أعضاء القيادة و الوزر اء في منتصف عسام بو 199

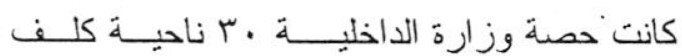

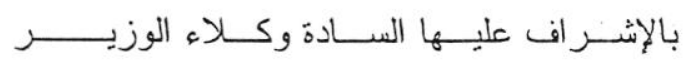
و المستشارين و المدر اء العامين ومن بدرجتهم. ^. عادل سعيد هـــادي " إعــداد وتنفيــذ التصـــاميم الأساسية للمدن" وز ارة التخطيط، در اسة رقـم (V)

$$
\begin{aligned}
& \text { تموز سهو19 ص ع-V. } \\
& 9 \text { ـ المصدر السابق ص V-V Vـ. }
\end{aligned}
$$

• 1. أنظر د. نجيل كمال عبد الرزاق " الإطار العام للتخطيط في العراق" بحث منشـــــور فــي مجلــة

الهندسة و التكنولوجيا I99 199 ـ مجلد ال عدد ؛. 1 ا. د. د. نجيل كمال عبد الرزاق مصدر ســـابق ص

$$
. \varepsilon \cdot-r v
$$

Y1. قانون المحافظات رقم 10 لسنة 1979 المعدل. با. ققانون إدارة البلديات رقم 170 لســنة ؛ 197 م

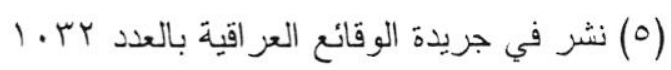

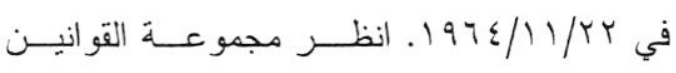
وقرارات مجلي قيادة الثورة و الانظمة و التعليمـات

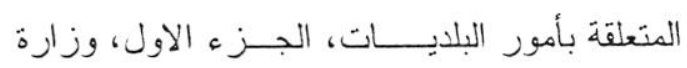

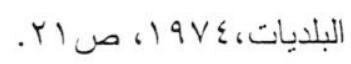

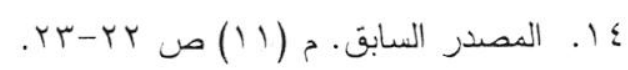

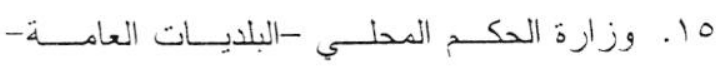

$$
\begin{aligned}
& \text { منجزات البلديات 197 19 19 19 صـ 1. } \\
& \text { 17. احسان فتحي " اسنتقدام التخطيط في العـــــراق، }
\end{aligned}
$$

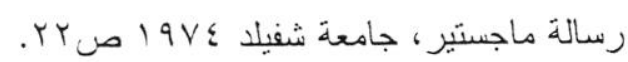

- عدم فرض الطابع الحضري علــى المســـوطنات التي يغلب عليها الطابع الريفي.

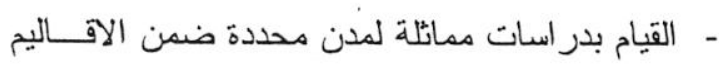
او ضمن محافظة و احدة.

\section{المصادر و الملاحظات}

ا. قانون التصميم الاساسي لمدينة بغداد رقـــم 107 لسنة الو9 ا ـ صدر بموجب قزآر مجلـس قيــادة

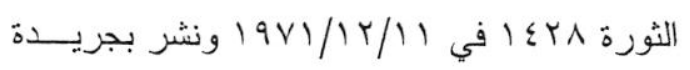

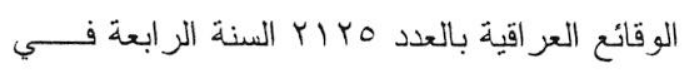

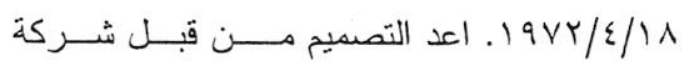

$$
\text { بولسيرفيس البولونية. }
$$

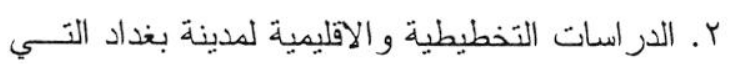

قام عدة باحثين وشركات او مؤسســــات عر اقيـــة

$$
\text { وأجنبية بها. }
$$

r. أبتدأ بأحداث الوحدات التخطيطية في المحافظــات

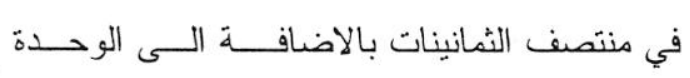
التخطيطية التي استحدث في منطقة الحكم الذاتــي في سنة 19V7.

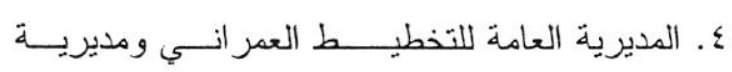
البلديات العامة ارتبطت بوزارة الداخلية بعد الغـلـه وز ارة الحكم المحلي بموجب قر ار مجلس قيــــادة

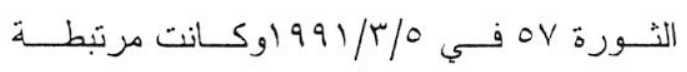
بوز ارات مختلفة. أنظر نجيل كمال عبد الـــزاق " تقييم فعالية عملية التخطيط الحضري في العــراق" رسالة دكتور اه غير منشورة- جامعة شفيلد 1917

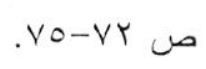

ه. " التصميم الأساسي لمدينــــة الموصــل " شــركة

انترناشنال الفرنسية ومكتب دار العهـارة 19 I. ." التصميم الأساسي لمدينة البصرة " شركة لوبن ديفيز ويكس فورستير كلكــــر بــور الانكلبزيــة و الاستشاري العر اقي. "التصميم الأساسي لمدينــــة كركوك " شركة ووكسيادس اسوشيتس انترناشـنال 


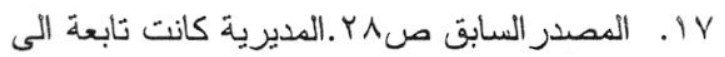
وزر اة الثؤون البلدية والقروية ثم وزارة البلديات.

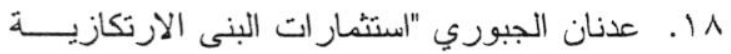
و النمو الحضر في في العـــراق"رســـالة دكتــور اه،

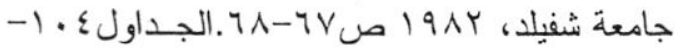
ه. 1 كذللك انظر الملحق رقم 1 من نفس المصدر.

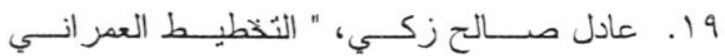

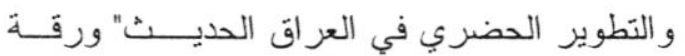
مقدمة الى الندوة العالمية في التخطيط العمر انـــي و تقنيات بناء المدن الجديدة المنظمة من قبل الامــم المتحدة وحكومة الاتحاد السوفيتي 1971 ـ صفحة

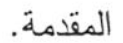

• Y. د. دعمان أمين الجليلي. مدير عــــام المديريــة العامة للتخطيط و الهندسة حتى عام ع 19 . . ا r. إحصائية عن عدد واختصاصات لكادر البلديات و المديرية العامة للتخطيط العمر اني في نهاية عام r 191 - وزارة الحكم المحلي يبين فيه ان عــد المخططين و المهندســين فــي المديريــة العامــة للتخطيط العمر اني انخفض الى (·) بــــلا مــن (0) - (0) في السبعينات. r. - الم. المصدر السابق.

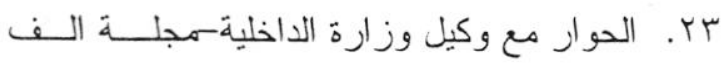

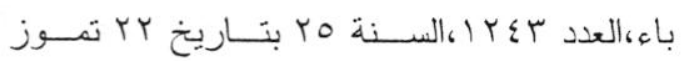
. $r \leqslant ص 199$. ؟ Y. . حملة تطويز •النواحي - مصدر سابق.

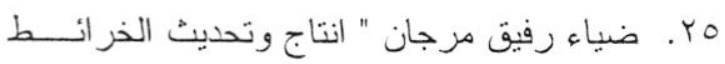
الرقمية و استخدامها في تخطيـــط المــدن" مركـز التخطيط الحضري و الاقليمي - جامعة بغـــــداد - 